\title{
Culture and corruption in The Picture of Dorian Gray
}

\author{
Paulo Augusto Wagatsuma
}

Mestrando em literaturas de expressão inglesa / UFMG

\begin{abstract}
This article analyses the supposed moral decadence in Oscar Wilde's novel based on the aesthetic trends of his time as well as his writings on the same topic and politics. It is argued that behind the horror tale of Dorian Gray's life lies a veiled critique to fin-de-siècle Victorian society.
\end{abstract}

KEYWORDS

Art, philosophy, decadence, evil, fin-de-siècle

\section{INTRODUCTION}

Discussing the ways in which society supposedly corrupts the individual, Jean-Jacques Rousseau asserts that philosophy has the dangerous capacity to loosen the bonds of mutual generosity and respect which tie people together. As soon as a man takes to philosophy, Rousseau writes, he becomes exceedingly proud and loses interest in other people and matters. "Family, fatherland, become for him words devoid of meaning: he is neither parent, nor citizen, nor man: he is a philosopher." ${ }^{1}$ It is not my focus here to discuss how this view was accepted. However, if we consider the term philosophy broadly as a set of thoughts and beliefs that guides a person's conduct, it can be said true that an attachment to philosophy can lead to the most undesirable consequences. History provides us with many examples. In literature, Oscar Wilde's The Picture of Dorian Gray depicts the perverse side of reason by showing that it can buttress human passions instead of fight them; and, in fact, that it can elevate them so far above social restrictions that to pursue their fulfillment as a matter of principle turns man into a transgressor of earthly and divine laws, an evil creature in war against the world. The Picture of Dorian Gray is a fine picture of the human clash as it takes place in the individual and collective levels. This clash both confirms and disagrees with the

\footnotetext{
${ }^{1}$ ROUSSEAU. Social Corruption, p. 172.
} 
classical theories of society, like Thomas Hobbes: peaceful coexistence requires a balance that is only achieved through laws, but Hobbes's biological metaphor for the state as an artificial human being is much more an emblem of the split nature of society than a symbol of harmony and cooperation.

\section{CONCEPTS OF MAN}

Different views on human nature can be traced in Wilde's novel, and the recurrence of those contrasting views contributes to the tone of conflict pervading the narrative. On the one hand, Lord Henry Wotton's aestheticism echoes to a certain extent the Rousseauean idea that civilization mars the individual's innate good. When first marveled by Dorian Gray's beauty, Lord Henry thinks the face on the portrait belongs to someone "unspotted from the world", 2 one whose mind has been preserved from the degrading intelligence of civilization, as if Dorian never thought at all. On the other hand, when the painter Basil Hallward confronts his sitter to explain the great amount of calumny being spoken against him, Dorian retorts: "Each of us has Heaven and Hell in him, Basil”, 3 arguing that also evil is an inborn feature of human nature. This latter view is closer to the proposition developed in Leviathan by Thomas Hobbes, for whom men in their natural state, that is, in the absence of laws, are evil and would kill each other to have what they needed, which means this capacity is intrinsic and not socially developed. It is due to what Hobbes calls the violent passions, stronger and hard-tocontrol impulses that can lead one to commit intemperate acts like murder. The state of nature is for Hobbes a state of war of "every man against every man"4 in which not even life would be certain, which drove individuals to seek the peace and prosperity afforded by laws. The Commonwealth, then, assures the individual bodily safety and the means to attain their ends. To put it briefly, it makes life possible in every way. But although it requires personal restraint, the freedom inside the Commonwealth is actually so vast that it allows some of its members, after accumulating a great amount of means material and intellectual, to attempt against itself. Dorian Gray resembles a myth, but it is a tale grounded on scientific, philosophical, and artistic arguments that prove the proposition above true and reveal the fragility of human beings before themselves.

\footnotetext{
${ }^{2}$ WILDE. The Picture of Dorian Gray, p. 19.

${ }^{3}$ WILDE. The Picture of Dorian Gray, p. 150.

${ }^{4}$ HOBBES. Leviathan, or Matter, Form, and Power of a Commonwealth Ecclesiastical and Civil, p. 85.
} 


\section{FROM MYTH INTO THE WORLD}

The first thing Lord Henry does after meeting the young Dorian Gray is to discover all about him because he is fascinated by the power of influences, both hereditary and of upbringing, in shaping an individual. The story of Dorian's parentage turns out to be a crucial element in his personality and it hints at his future role in the world.

Dorian, as Lord Henry finds out, is the outcome of his mother's affair with a man of inferior status, at the end of which the man is murdered on her father's orders. Soon after giving brith, Dorian's mother dies, too, leaving the child to the care of his bitter grandfather. This disastrous background hints at Dorian's monstrous condition: first, because his origins are related to crime and sin, which means that symbolically Dorian would be condemned to an equally sinful life; second, because it suggess that Dorian's passionate, crime-inclined temperament is an atavistic quality that would later determine his actions, even in spite of himself; third, because it gives Dorian a tragic, myth-like genesis that partly explains his extraordinary circumstances, his unmatched beauty, his exacerbated evil, and eventually his wish to kill himself.

According to Julio Jeha, the Greeks believed the monster was "a prodigy, a warning against an infringement of the pax deorum". ${ }^{5}$ The monster would be, then, a horrid form of punishment sent to a people in a particular place and time because they disrespected the divine commandments. The Victorian society depicted in Wilde's novel proves well deserving of such punishment, for in breaking the laws of the Commonwealth they are also breaking man's covenant with the Creator, since it is God's wish that the Commonwealth be obeyed for life to prosper. To offend it is to offend Him. In this context, we can understand Dorian Gray as a monster inflicting the Victorians with the shame of their own sins. However, Dorian must not be seen as the strange, frightening other; he is the same in his entire monstrosity: his fortunate position, his mentality, and pursuits are things made possible by the way he and men chose to live. Like Joyce Carol Oates writes, the social maladies portrayed in the novel are "symptoms of a highly advanced and sophisticated civilization itself", so that Dorian's deeds are greatly influenced by a philosopher in his own way, Lord Henry Wotton, and an artist, Basil Hallward. Wilde's protagonist cannot be understood without those two representatives of his age beside him.

\footnotetext{
${ }^{5}$ JEHA. Monstros como metáforas do mal, p. 20.

${ }^{6}$ OATES. The Picture of Dorian Gray: Wilde’s Parable of the Fall, p. 426.
} 


\section{SELF-PORTRAITS}

The novel opens with Basil Hallward and his languid friend beholding the painter's new chef d'œuvre. One can soon see what these men's main occupation is. As Victorian aristocrats, they are at the top of the nineteenth-century socio-political hierarchy, and this position allows them to devote almost exclusively to the work of contemplating. In "The Critic as Artist,” one of Wilde's essays on aesthetics, the debater Gilbert argues in favor of doing nothing at all, as he puts it, by saying that "in the opinion of the highest culture it is the proper occupation of a man". ${ }^{7}$ For Wilde, art is the manifestation of a fully developed personality, and criticism is that of a yet superior one, for he contends that whereas even the less enlightened can attempt to make, they cannot attempt to criticize at all. He maintains that society as a whole gains when an artist or a critical mind realizes their perfection. Based on these reflections, we could expect that "the elect" should perfect their souls before everyone else, but in Dorian Gray what they do instead is cause their ruin, which is partly Wilde's critique of his time. Appropriately, a work of art becomes the mirror where they can contemplate their corruption.

Dorian and Lord Henry meet each other when when the portrait is just about to be finished. Harry is immediately touched by the boy's good looks, and he wishes to influence the boy with his own ideas. He believes what he is doing is bad because "to influence a person is to give him one's own soul”, 8 and as a result that person will never develop his own personality. It is a questionable theory since influence of all kinds is inevitable, but its consequences do not stop him short. In chapter I, Basil says the discovery of a new means of art is one of the most extraordinary moments in life, and for Henry Wotton such is the feeling at discovering Dorian. A means is exactly how he sees his protégé. He realizes his soul through Dorian's body; his desires for boundless pleasure find form and expression in the lad, and just like a work of art gains a life of its own, so does Dorian embody his master's thoughts so well that he begins to develop them independently. In this sense, the opening scene shows both Hallward and Wotton working on their masterpieces. Ignoring the monstrous pact that gave Dorian eternal beauty, Lord Henry is satisfied at the fact that he is the one responsible for turning Dorian into the ideal of his age. However, the ideal represented by Dorian Gray can be seen to be the evil side of man stirred by the passions and

\footnotetext{
${ }^{7}$ WILDE. The Critic as Artist, p. 153.

${ }^{8}$ WILDE. The Picture of Dorian Gray, p. 20.
} 
made more dangerous by the very thing society depends on, reason.

The "strange panegyric on youth" through which Lord Henry gains Dorian's sould values the individual above everything, and sees in laws an impediment to the full realization of one's self: "The terror of society, which is the basis of morals, the terror of God, which is the secret of religion - these are the two things that govern us." ${ }^{\text {9 }}$ Here, we must follow Houston Baker Jr. when he maintains that "we should read and interpret the novel within the framework of Wilde's major ideas". ${ }^{10}$ Baker Jr. explains that "for Wilde the progress of society was dependent upon the progress of the individual”, ${ }^{11}$ and therefore everyone should have as their primary goal in life to strive for their perfection - whatever Wilde meant by the term. As fine means of molding and developing personality, art and criticism have an essential role in that improvement. But the idealistic Wilde believed in changing society, not in rebelling against it. This is what Henry Wotton does through his perverted notions of Hedonism and individualism. He believes one must live life to the very fullest if one wishes full realization, but this quest entails ignoring other people's rights and indulging in experiences that morals and laws forbid. He says,

The mutilation of the savage has its tragic survival in the self-denial that mars our lives. We are punished for our refusals. (...) The body sins once, and is done with its sin, for action is a mode of purification. Nothing remains but the recollection of a pleasure, or luxury of a regret. The only way to get rid of a temptation is to yield to it. Resist and your soul grows sick with longing for the things it has forbidden to itself, with desire for what its monstrous laws have made monstrous and unlawful. ${ }^{12}$

It is clear that Lord Henry is not merely a libertine. Inaccurate though some of his points may be, he treats his disciple as a "study" for which he employs "scientific methods". Several critics have pointed out that Wilde was thoroughly familiar with scientific theories of his day. Discussing the place of ethnology among those, Robert Mighall explains that “Wilde’s suggestion that 'self-denial' was actually a 'savage' vestige of a less evolved culture perverts the orthodox application of these concepts." ${ }^{13}$ What the critic calls orthodox might be a connection with Rousseau, for whom men in the natural state would not kill each other, but instead would survive exactly through self-denial. He writes that nature has endowed men

\footnotetext{
${ }^{9}$ WILDE. The Picture of Dorian Gray, p. 21.

${ }^{10}$ BAKJER JR. A Tragedy of the Artist: The Picture of Dorian Gray, p. 350.

${ }^{11}$ BAKJER JR. A Tragedy of the Artist: The Picture of Dorian Gray, p. 351.

${ }^{12}$ WILDE. The Picture of Dorian Gray, p. 21.

${ }^{13}$ MIGHALL. Introduction, p. 235.
} 
with pity, a sentiment that, "by moderating in every individual the activity of self-love, contributes to the mutual preservation of the entire species”. ${ }^{14}$ For Lord Henry, however, this good feature of human nature is a terrible flaw. His unorthodox application of concepts means that any feeling that makes a man tend towards another in need is bad because it prevents him from reaching the ideal stage of individualism. Following Lord Henry's argument, a "superior” culture such as nineteenth century Europe ought to have got rid of that undesirable savage vestige, but Dorian Gray ultimately shows that this is impossible.

After their Dorian and Lord Henry's first conversation, Basil shows them the finished portrait. By congratulating the artist and calling the sitter to come and take a look at himself, Lord Henry is cunningly enticing the naïve Dorian to become aware of his youth and make the most of it. The lad comes, and the crucial event happens. First, he delights at his extraordinary beauty. Then, he is shocked: for the first time he really feels what Harry had been telling him. As man and picture stand in front of each other, a confrontation takes place. One is the triumph of nature, the other is the triumph of men, but the latter, a mere copy of the first, will remain unspoiled through time while the real person will become "dreadful, hideous, and uncouth”, ${ }^{15}$ The irony in their fate strikes Dorian as a great injustice, and moved by this feeling he declares he would give his soul for the eternal beauty that only the portrait can boast having. That prepares the ground for one of the main issues dramatized by Dorian's story.

Dorian's giving up his essence for the sake of appearance, though a unique act as he does it, is relatable to the late-Victorian attitude towards life which came to be known as fin de siècle or decadence. In literature, Oscar Wilde was one of the main names in Britain. In the novel, Lord Henry is its best representative. Though the term has always been controversial, it is a consensus that decadence was a cult of the artificial over the natural. What is more, Bernard Bergonzi explains that there was among the decadents "the conviction that all established forms of intellectual and moral and social certainty were vanishing", ${ }^{16}$ which partly explains Dorian’s behavior. The decadent tenets mark his journey through pleasure, sin, and ultimately regret and death.

\section{“SO MUCH MORE THAN REAL LIFE”}

\footnotetext{
${ }^{14}$ ROUSSEAU. Social Corruption, p. 177.

${ }^{15}$ WILDE. The Picture of Dorian Gray, p. 27.

${ }^{16}$ BERGONZI. Aspects of the fin-de-siècle, p. 464.
} 
After meeting Lord Henry, Dorian Gray is a very different man. He is full of passion and eager the know the world. In this spirit, he meets Sybil Vane, a young actress, who sweeps him right off his feet: “How different an actress is! Harry! Why didn’t you tell me that the only thing worth loving is an actress?” ${ }^{17}$ The question underlines that most of Dorian's passion is due not to Sybil's matchless beauty or personality, but rather because she can act celebrated females characters of the stage, such as Juliet and Imogen. Dorian knows almost nothing about Sybil Vane the person, but this only makes her more interesting, not only to him but also to Harry: "When is she Sybil Vane?” "Never.” "I congratulate you.”18

Behind this shallow appreciation of Sybil lies the decadent love of art and artifice. Decadents value things and people not for what they really are, but rather for what they appear to be, even if those appearances serve only as a means to conceal unpleasant realities or, in Dorian's words, to multiply personalities. Without her gift of pretending, Sybil would not have become Dorian's heroine, but the young naïve girl fails to understand that Dorian values her as a means to have other, more noble, women. When Sybil decides to quit acting to embrace real life as Mrs. Gray, she stabs Dorian in the heart: she acts terribly and contradicts Dorian at the presence of Harry and Basil, whom he had given his word for her talent.

To Lord Henry it is not a problem at all that Sybil should be a bad actress, for her beauty is enough: "She is beautiful. What more can you want?" ${ }^{19}$ Dorian, however, is not so easily persuaded. The very thing his romance had been built on, i.e. the fantasy of loving the heroines of the theater, had been shattered before his eyes and made him ridiculous him before his friends. Sybil's explanation to her bad performance shocks Dorian even more, and as a result he breaks up with her. He crushes her feelings as if he were acting and she were merely a creature of paper: "I loved you because you were wonderful, because you had genius and intellect, because you realized the dreams of great poets and gave shape and substance to the shadows of art." ${ }^{20}$ Soon after being repudiated so violently, the hopeless Sybil commits suicide.

Sybil's death is the first and best example of how Dorian's evil is a union of passions and perverse intellect. He humiliates the girl in a fit of anger, thinking her ridiculous for lying prostrated at his feet, but he only does so because he is so concerned with the artificiality of

\footnotetext{
${ }^{17}$ WILDE. The Picture of Dorian Gray, p. 51.

${ }^{18}$ WILDE. The Picture of Dorian Gray, p. 54.

${ }^{19}$ WILDE. The Picture of Dorian Gray, p. 83.

${ }^{20}$ WILDE. The Picture of Dorian Gray, p. 85.
} 
his reaction. It is clear that Dorian never really loved Sybil, for he was never ready to deny himself for her. What he called love was just infatuation. Acting was everything the girl meant to him, and beauty to Lord Henry. They found absolutely nothing else interesting about Sybil Vane the real person, her family, background, and above all her scant knowledge of the world.

After the incident, still dominated by anger, Dorian roams around London, and eventually finds himself in the marginalized areas of the city. This is when he starts becoming a monster: the dark side of his nature is taking over him and he loses power over his actions. Described as a lair to all sorts of bad creatures, the rough areas of the city are to become his proper habitat:

He remembered wandering through dimly-lit streets, past gaunt black-shadowed archways and evil-looking houses. Women with hoarse voices and harsh laughter had called after him. Drunkards had reeled by cursing, and chattering to themselves like monstrous apes. He had seen grotesque children huddled upon door-steps, and had heard shrieks and oaths from gloomy courts. ${ }^{21}$

The description, particularly the choice of adjectives, show the novel is conscious of the issue of monstrosity it deals with. Dorian becomes a liaison between the two different worlds, the poor and the wealthy, showing that crime and degradation are not necessarily triggered by poverty and savagery: having their roots in every human being, they also belong to the rich and cultivated in the most calculating ways.

The following day Dorian finds the portrait with an odd touch to it he had never noticed before, and reflecting on the events of the past night realizes what had happened to him and his painting. A struggle takes place in his conscience over the way he had treated Sybil. Dorian swings between regret and pride several times while he ponders, but eventually his egoism prevails. He thinks what Sybil had done to him was much worse than what he had done to her. Later on, Lord Henry comes over and his powerful influence on Dorian drowns the last bit of repentance that might have survived. Once again their conversation underscores the decadent principles behind their actions, this time when they discuss reasons not to grieve for Sybil. Sybil's death had been a grand finale, "a wonderful ending of a wonderful play",22 as if even her suicide had been a fitting ending to a tragic love story such as that of Romeo and Juliet. To Lord Henry, Sybil does not deserve their sorrow because in his mind she is totally devoid of significance as a person: "The girl never really lived, so she has never really

\footnotetext{
${ }^{21}$ WILDE. The Picture of Dorian Gray, p. 86.

${ }^{22}$ WILDE. The Picture of Dorian Gray, p. 98.
} 
died. To you at least she was always a dream, a phantom... .23 With such considerations, Dorian and Harry bury Sybil Vane in the shallow ground of their selfishness and revere her memory as a dream-like creature who pleased their love of artificiality for a while and then was gone.

\section{“SWEET OR BITTER AS THEY MIGHT BE”}

After Sybil's death, Dorian says, as if he had forgotten what he had brought upon her, that his affair with the girl was a wonderful experience. Lord Henry agrees by acknowleding he would like to have a similar experience. This perverse appreciation of a terrible event like suicide is possible to them because they value experiences in general, regardless of their results. Experience for its sake is the chief tenet of late Victorian decadence, and it is also the main force moving Dorian to fulfill his passions, sear his soul, and cause his and other people’s ruin.

Russell Goldfarb defines that decadents emphasized "the value to be gained from experience of all sorts and from indulgence in a life of sensations” ${ }^{\text {,2 }}$. In Dorian Gray both aspects are comprised in the new Hedonism envisioned by Lord Henry, which can be understood as a symbol of the decadent opposition to a prohibition-based society like ours. Thinking about its benefits, Dorian stresses that “[i]ts aim, indeed, was to be experience itself, and not the fruits of experience, sweet or bitter as they might be”. ${ }^{25}$ Moreover, Dorian thinks that in that new reality sensations would not be cut short, but rather stimulated and elevated into "elements of a new spirituality, of which a fine instinct for beauty was to be the dominant characteristic.” Dorian and Lord Henry believe the senses can cure the soul in a cathartic way, but, they argue, the world's restrictions have prevented it from happening.

Besides Hedonism, another symbol of decadence that also propels Dorian is the book Lord Henry lends him, and on which the lad bases his own life. The book has been identified as Joris-Karl Huysman's À Rebours (Against the Grain), one of the major decadent literary works. Dorian is fascinated by it because its protagonist, a young, wealthy, passionate man like himself, seeks to realize his passions with a combination of both "the romantic and scientific temperaments” that makes his search a methodic one. This certainly accounts for Lord Henry’s artistic/scientific approach to Dorian, his own study, and also for the non-

\footnotetext{
${ }^{23}$ WILDE. The Picture of Dorian Gray, p. 100.

${ }^{24}$ GOLDFARB. Late Victorian Decadence, p. 373.

${ }^{25}$ WILDE. The Picture of Dorian Gray, p. 126.
} 
judgmental way in which both of them regard the results of their experiences. The narrator tells us that for many years after first reading the "poisonous book" Dorian "never sought to free himself from it," trying to repeat the protagonist's deeds so closely that he thought the book was his own life written before he lived it. Inspired by these two symbols of decadence, and using his talents, especially the gift/curse of eternal youth, Dorian will challenge the world and try to get the closest possible to his master's idealized life.

As he indulges in forbidden pleasures and sins, Dorian is searching to fulfill his passion for beauty in every moment and through every means of the body. For philosopher David Hume, anything is beautiful that "is fitted to give pleasure and satisfaction to the soul”, ${ }^{26}$ but Hume also contends that convenience and utility help define our judgment of beauty. Dorian seems to have dismissed these two aspects, for his sole aim is to have form and pleasure for their own sake. This implies that in his search for experiences he saw no barriers in ethics, laws, self-denial, or morals, things that would make an ordinary person give up a pursuit like his. If we look for what philosophy has said specifically about morals, we will find that Hume considers them to be rooted in the human being, unlike virtue and vice, which he considers artificial notions. In light of this, Dorian's disrespect of morals, among other things, becomes particularly serious because by trying to sever them off he is actually attempting to break with nature and God, and the consequences of doing so prove the worst both to himself and society, for in order to achieve his ideal Dorian embraces evil "simply as a mode through which he could realize his conception of the beautiful” and starts to subject people to the most cruel methods he can fancy.

Even though he tries to preserve his good name in society by being an impecable host, Dorian can no longer conceal the monster he has become. His prolonged absences give rise to bad conjectures, his name becomes a byword for infamy, and his circle of acquaintances begins to ostracize him. Dorian, who believes to be in a mission against the "uncomely puritanism" of his age, is not bothered by that; he is rather encouraged to seduce friends into his corrupted lifestyle, which he easily does with his charm. Then, he delights at witnessing the distortions grow on the portrait locked up at the top of his house.

Shocked by the accusations he hears from respectable men, Basil Hallward entreats Dorian to deny everything. At this moment the reader is allowed an insight into the seriousness Dorian’s behavior:

Why is your friendship so fatal to young men? There was that wretched boy

\footnotetext{
${ }^{26}$ HUME. A Treatise of Human Nature, p. 350.
} 
in the Guards who committed suicide. You were his great friend. There was Sir Henry Ashton, who had to leave England, with a tarnished name. You and he were inseparable. What about Adrian Singleton, and his dreadful end? What about Lord Kent's only son, and his career? I met his father yesterday at St. James's Street. He seemed broken with shame and sorrow. What about the young Duke of Perth? What sort of life has he got now? What gentleman would associate with him ${ }^{27}$

Those are just a few innuendoes contained as to Dorian's unspeakable sins, as someone put it. Bolder passages go as far as to suggest adultery and sexual depravation (women would grow pale upon seeing him). And despite so much evidence against him, it is important to remember that Dorian is not the only rotten apple in the bag. His argument that he didn't "teach the one his vices, and the other his debauchery," along with Basil's acknowledgment that "the English society is all wrong," are evidence that Dorian is the exacerbation of a malady that was there before he arrived. As proposed above, Dorian can be seen metaphorically as a monster sent to horrify the Victorians with their own sins. Perhaps the best instance is literature itself in the shape of the "poisonous" novel Dorian likes so much, as it illustrates Wilde's contention in "The Critic as Artist” that life imitates art, art which, Wilde argues elsewhere, is a privilege of Dorian's idle social stratum, made by themselves and for their own appreciation.

Basil’s reproach annoys Dorian, especially when the painter says that in order to really know his friend he would have to see his soul. Dorian is appalled by those words, but the irony is so piercing that he is encouraged to invite Basil to look at his soul. Since the painter will not stop rebuking him, Dorian thinks it is appropriate that he should look at canvas he himself painted: "Years ago, when I was a boy, (...), you met me and flattered me, and taught me to be vain of my good looks. One day you introduced me to a friend of yours who explained to me the wonder of youth, and you finished a portrait of me that revealed to me the wonder of beauty. “28 Thus Dorian reminds Basil that the artist himself spoiled his ideal by teaching it to be self-conscious, and by putting into the portrait, in Baker Jr's words, "his own idolatry and worship of the physical embodiment of his ideal”, when he should have presented only "an abstract sense of beauty" ${ }^{29}$ Basil's shock at seeing his masterpiece so terribly altered fills Dorian with rage and regret, and he murders his creator. The room, so far a place where Dorian would hide supernatural evidence, now becomes the scene of a bloody crime and a

\footnotetext{
${ }^{27}$ WILDE. The Picture of Dorian Gray, p. 144.

${ }^{28}$ WILDE. The Picture of Dorian Gray, p. 149.

${ }^{29}$ BAKER JR. A Tragedy of the Artist: The Picture of Dorian Gray, p. 358.
} 
capital sin.

\section{MYRIAD LIVES}

Later Dorian attends a party. The scene is a jewel in its detailed depiction of Victorian social life, but Dorian is too distressed to enjoy it and goes home early. There he burns Basil's clothes, the only evidence left, and after that starts to feel worse. Then, he reaches for some “green paste waxy in luster," which Robert Mighall suggests could be hashish, but decides he needs more than that and makes his way to an opium den.

In the huge contrast of setting it presents, this scene is one of the best instaces of another major theme in the novel, namely double life, which was common to a good deal of the literature of the period. Mighall explains that books like Dr. Jekyll and Mr. Hyde and Dorian Gray caused impact among contemporary readers because the experience of duplicity was "far from unique" 30 to fictitious persons. It was in fact closely related to the theatrical artificiality of the Victorian social codes. "The native land of the hypocrite,” as Dorian calls it, lives in a state of illusion that forces one to play roles all of the time, but the problem with trying to turn social life into a delightful play is that, if it requires that one be what one is not in order to be respectable, it will consequently leave one no choice but to be oneself where this is unacceptable, outside the law.

Dorian seems to be in accord with that, for his impeccable role on society's stage helps him dismiss rumors concerning his conduct in the backstage. He is actually an opium addict, but, as far as this is possible, there is some method in his craving: he wants to numb the senses to empty his mind of the ghosts haunting it, so he ventures into the foul areas of London at night where the drug and other illegal things are sold, this being his most frequent transgression for the sake of experience. As he rides to forgetfulness, however, Dorian is reminded that reality, especially at the bottom of the social pyramid, can be quite the opposite of the artificial idyll of his life.

Ultimately, Dorian shows with his double life that in Victorian society from sublime to horrid is metaphorically but a step. He shifts easily from being a most beloved gentleman among ladies to most hated client among prostitutes, from "Prince Charming” to "devil's bargain”, and from innocent young man to cold-blooded murderer. As he sneaks through the narrow streets one night, Dorian is found by Sybil Vane’s brother, James Vane, and faces the

\footnotetext{
${ }^{30}$ MIGHALL. Introduction, p. xiv.
} 
last obstacle until he achieves earthly impunity to his monstrous deeds.

For many reasons James Vane is Dorian Gray’s counterpart. James is poor and Dorian is rich, but James is an offspring of class conflicts, too. His father is said to have been a highly connected gentleman, and his mother is a low class actress. Ms. Vane tells her son "I knew he was not free”, meaning their love was, like Dorian's parents', doomed by the social gap between them. Besides, she gives to understand that James's father did not live long after his son was born. James, who never knew exactly why he never met his father, curses him as he believes he only took advantage of his mother and then abandoned her. This fills him with resentment at the upper classes, so he grows suspicious when he finds out Dorian and Sybil are engaged, as if he could predict what was to happen to her later. He could never predict, however, that the man he is hunting looks eighteen years younger than he is. Dorian is helped out of the predicament by his mask of youth and deceives James long enough to run away and hide. Since no one Sybill's Prince Charming was, Dorian was lucky enough to escape punishment. This compells James to seek justice with his own hands, but by an act of divine providence, so to speak, James is accidentally shot dead in Dorian's country premises, leaving the terrified Dorian free once again.

\section{“HE WOULD DESTROY IT"}

After James Vane's death, Dorian resumes his life. At this point, he stands as the victory of the individual over society. He challenges and crushes its principles of collective respect and restraint for the welfare of all. By failing to apply the law accordingly, the state exempts Dorian from the guilt he was supposed to feel for his trespappses. He thinks that life is really ruled by chance: "[s]uccess was given to the strong, and failure was thrust upon the weak." 31 So he concludes that even under laws men are on their own, and therefore one cannot be blamed for doing what he must to survive, a thought which pleases him as he owns the means not only to survive, but also to enjoy life.

To trample over society Dorian and Lord Henry challenge human nature in the course of their lives. Though they behave respectably on the surface, they alienate themselves from the world by ridding themselves of important natural features. The first is sympathy, a feeling Hume considers essential for the good of humans as it is the only way one can sympathize with the suffering of others. Lord Henry's statement "I can sympathize with everything,

\footnotetext{
${ }^{31}$ WILDE. The Picture of Dorian Gray, p. 191.
} 
except suffering”, ${ }^{32}$ which Dorian eventually makes his own, shows that they refuse to have the social spirit necessary for coexistence because it implies limits. As a result, they ignore the harm they cause others and look for satisfaction regardless of whether it is lawful or not. Besides, Dorian and Lord Henry also fight conscience. "Conscience and cowardice are really the same things", 33 Lord Henry says; in other words, it prevents one from exploring all sensations of life because one is aware that many of them are forbidden. Thus, conscience works in man's mind as a set of laws, but as a decadent and a Hedonist Lord Henry abhors authority of any kind and does whatever it takes to eliminate his sympathy, conscience, and his soul, following the supposed skepticism of his age: "No: we have given up our belief in the soul."34 That way he is free to indulge in sins and crimes without the burden of politics, religion, or anything else, but if he really does such things or leaves to his creation, Dorian, is not clear in the novel.

Unlike Lord Henry, Dorian is a confirmed sinner and criminal, and he is troubled by conscience. He has the picture to give form to his evil essence, and being hunted down and almost killed urges him to change. However, conscience is not able to open his heart to humaneness; it just scratches his huge egotism, for he wants to keep his lifestyle at the same he eliminates the constant reminder of his monstrosity, the portrait. At the end of the novel, Dorian thinks that his recent good action, sparing a country girl from an affair with him, might have restored the painting. He looks at it, but finds it as terrible as before, for he had spared the girl out of vanity. Realizing that the portrait will be there all his life to ashame and humiliate him, Dorian thinks just like his soul is in it, so is his conscience. This role of the portrait is emphasized throughout the novel, but only at the ending does Dorian conclude that he must get rid or it in order to be free: "Yes, it had been conscience. He would destroy it."35

So the reader is told that Dorian advances to the picture with a knife and stabs it, but actually stabs himself. His death is as ironic and naïve as Narcissus's, who kills himself after trying to grab his own image on the water. Dorian had already broken the covenant with the Commonwealth and destroyed his morals, but by trying to destroy his conscience he is attempting to break the bond tying him to nature and God. Paul Ricœur writes that "[w]ith

\footnotetext{
${ }^{32}$ WILDE. The Picture of Dorian Gray, p. 41.

${ }^{33}$ WILDE. The Picture of Dorian Gray, p. 10.

${ }^{34}$ WILDE. The Picture of Dorian Gray, p. 205.

${ }^{35}$ WILDE. The Picture of Dorian Gray, p. 212.
} 
guilt, 'conscience' is born”, ${ }^{36}$ meaning that conscience exists because there is sin, which produces guilt. Sin, according to Ricœur, is "the loss of the bond with the origin", ${ }^{37}$ a violation of man's covenant with God by which he was given the gift of life. Therefore, conscience can be seen as a device meant to remind man of the covenant, and which Dorian tries to switch off. After succeeding in becoming an unnatural creature on earth, Dorian Gray attempts directly against the maker, and is punished to die. Dorian's soul returns to his body and his splendorous face is revealed once again on the canvas as eternal proof of his purity back when he was an uncorrupted ideal of creation.

By brining together artistic, scientific, and political issues into a story which he himself recomends, ironically, should be on the surface, Wilde created a monster who embodies not only the worst vices, but, crucially, the best virtues and triumphs of the civilized human being, to produce weatlh, to abstract, and to create beauty. Perhaps Dorian Gray's biggest sin was to take hold of these virtues and corrupt them to the worst possible end, the lessening of the individual. This is partly Wilde's critique of his culture, which at the turn of the $19^{\text {th }}$ century believed itself superior to any other and yet was falling victim of its own achievements. The novel illustrates what Wilde saw as his corrupted ideal, an ideal he envisioned in the essay "The Soul of Man under Socialism," where he puts forward his theory of the true Individualism: the perfection of society depends on the perfection of the individual, or else we will be subject to monsters of our own fabrication.

\section{RESUMO}

Este artigo analisa a suposta corrupção moral no romance de Oscar Wilde baseado nas tendências estéticas de sua época e seus próprios escritos sobre o mesmo tópico e política. Argumenta-se que por trás da história de terror de Dorian Gray jaz uma crítica velada à sociedade fin-de-siècle vitoriana.

\section{PALAVRAS-CHAVE}

Arte, filosofia, decadência, mal, fin-de-siècle

\footnotetext{
${ }^{36}$ RICEUR;. The Symbolism of Evil, p. 143.

${ }^{37}$ RICEUR;. The Symbolism of Evil, p. 103.
} 


\section{REFERENCES}

BAKER JR., Houston. A Tragedy of the Artist: The Picture of Dorian Gray. NineteenthCentury Fiction, 24.3, p. 349-355, 1969.

BALDICK, Chris. In Frankenstein's Shadow: Myth, Monstrosity, and Nineteenth-Century Writing. Oxford: Clarendon Press, 1987.

BERGONZI, Bernard. Aspects of the fin-de-siècle. In: POLLARD, Arthur (Ed.). The Victorians. New York: Penguin, 1993. p. 463-482.

BROWN, R. D. Suetonius, Symonds, and Gibbons in The Picture of Dorian Gray. Modern Language Notes, 71.4, p. 264, 1956.

GOLDFARB, Russel. Late Victorian Decadence. The Journal of Aesthetics and Art Criticism v. 20, p. 369-373, 1962.

HOBBES, Thomas. Leviathan, or Matter, Form, and Power of a Commonwealth Ecclesiastical and Civil. Chicago: Encyclopedia Britannica, 1984.

HUME, David. A Treatise of Human Nature. Middlesex: Penguin, 1969.

JEHA, Julio. Monstros como metáforas do mal. In: . (Org.). Monstros e monstruosidades na literatura. Belo Horizonte: Editora UFMG, 2007. p. 9-31.

LAWLER, Donald; KNOTT, Charles E. The Context of Origin: Suggested Origins of Dorian Gray. Modern Philology, 73.4, Part 1, p. 389-398, 1976.

MIGHALL, Robert. Introduction. In: WILDE, Oscar. The Picture of Dorian Gray. London: Penguin, 2003. p. ix-xxxiv.

MIGHALL, Robert. Notes. In: WILDE, Oscar. The Picture of Dorian Gray. London: Penguin, 2003. p. 231-253.

OATES, Joyce Carol. The Picture of Dorian Gray: Wilde's Parable of the Fall. Critical Inquiry, v. 7, p. 419-428, 1980.

PETERS, Robert L. Toward an "Un-definition" of Decadent as Applied to British Literature of the Nineteenth Century. The Journal of Aesthetics and Art Criticism, v. 18, p. 258-264, 1976.

RICEER, Paul. The Symbolism of Evil. Trans. by Emerson Buchanan Boston: Beacon Press, 1969.

ROUSSEAU, Jean-Jacques. Social Corruption. In: RORTY, Amélie Oksenberg. The Many Faces of Evil: Historical Perspectives. London; New York: Routledge, 2001. p. 172-178.

RYALS, Clyde de L. Toward a Definition of Decadent as Applied to British Literature of the Nineteenth Century. The Journal of Aesthetics and Art Criticism, v. 17, p. 85-92, 1958.

SEARGROATT, Heather. Hard Science, Soft Psychology, and Amorphous Art in The Picture of Dorian Gray. Studies in English Literature 1500-1900, v. 38, p. 741-759, 1998.

WILDE, Oscar. The Critic as Artist. In: . Essays. London: Methuen, 1950a.

WILDE, Oscar. The Decay of Lying. In: Essays. London: Methuen, 1950b.

WILDE, Oscar. The Soul of Man under Socialism. In: . Essays. London: Methuen, 1950c.

WILDE, Oscar. The Picture of Dorian Gray. London: Penguin, 2003. 